\title{
The Role of Social Media Networks in Committing the Criminal Behavior Among the Young People in the Jordanian Society from the Perspective of the Students of the Jordanian Universities
}

\author{
Dr. Abdullah Salem Al-Darawsheh (Corresponding author) \\ Al-Hussein Bin Talal University
}

Dr. Ghadeer Pernes A doub Al -Zaben

Al- Balqa Applied University

Received: December 9, 2019 Accepted: January 11, 2020 Published: March 7, 2020

doi:10.5296/ijld.v10i1.16629 URL: https://doi.org/10.5296/ijld.v10i1.16629

\begin{abstract}
This study aimed at identifying the role of social media networks in committing the criminal behavior among the young people in the Jordanian society from the perspective of the students of the Jordanian universities. In order to achieve the study objectives, the researcher developed a questionnaire to collect data. The research also used the simple random sampling as a method for selecting the study sample that consisted of (595) respondents. The results concluded the following results:

The results revealed that the most popular and used social networking among the young people is the Facebook, with a percentage of (68\%), followed by Whats App with a percentage of $(25.2 \%)$, and in the last rank, Twitter, with a percentage of $(6.7 \%)$.

As for the role of social networking in committing the criminal behavior among the young people in the Jordanian society from the perspective of the students of the Jordanian universities, the first place was for hacking the personal data and violating the privacy of others, with a mean of (4.11) and a standard deviation of (0.75), followed by tempting the young people in order to join the terrorist, extremist and delinquent groups, with a mean of (4.09) and a standard deviation of (0.74). The third rank was for the dissemination of rumors and slandering others, with a mean of (4.01) and a standard deviation of (0.66).
\end{abstract}


The results showed that there are no statistically significant differences at $(\alpha \leq 0.05)$ for the role of social networking in committing the criminal behavior among the young people in the Jordanian society from the perspective of the students of the Jordanian universities due to the variables of ( gender, age, income, educational level, faculty).

Based on the results, the study recommended a number of recommendations.

Keywords: social networking, criminal behavior, young people

\section{Introduction}

The human societies, either as developing or developed, witness a technological revolution which is considered as one of the most important sources of power at the level of the contemporary world. It has a considerable role in making core changes in all the social, political, economic, cultural and ethical domains. The importance of social networking in the twentieth century has been dominant due to the extensive available information and the development of modern technological methods which facilitated the transmission of ideas, information, skills, attitudes and experiences from one individual to another. This technologyenabled users to communicate with each other at any time, in addition eliminating the geographical borders as well as facilitating the process of sending messages, data and information without conditions (Al-Mansour, 2012).

Therefore, the social networking sites (Facebook, Twitter and WhatsApp) have become widespread and widely used among different people and groups all over the world. They are also considered as the best communication methods for exchanging opinions and ideas between individuals through which they can individuals publish their ideas and discuss them with each other. These networks have an important role in promoting knowledge transfer and acquisition, gaining more information, publishing their innovation as well as promoting their social relationships and sharing others in social events. However, they have other negative effects on the individual, family and society represented by disseminating rumors and chaotic events that would threaten the stability of the community (Moustafa, 2014).

Furthermore, the social networks enable users to communicate under unanimous identity that can't be monitored and their electronic source can't be identified easily. This helped the young people to commit the criminal behavior in the light of the absence of family surveillance as well as the absence of the role of enhancing the awareness by the religious, cultural and educational institutions, as these institutions have a prominent role in educating people about the risks of social networks.

The Hashemite Kingdom of Jordan is a part of this world, and thus it faces the risks of social media networks, especially among the young people who use these sites more frequently. Therefore, this study aimed at identifying the role of social media networks in committing the criminal behavior among the young people in the Jordanian society from the perspective of the students in the Jordanian universities.

\subsection{The Study Problem}

The study problem lies in identifying the role of social media networks in committing the 
criminal behavior among the young people in the Jordanian society from the perspective of the students of the Jordanian universities, where these social media networks have become a serious source of risk and anxiety for the human societies. They have harmful impact on the individual and society as well due to the high speed in transmitting information which may include harmful content related to motivating people to commit criminal behaviors that would disrupt the social system by publishing files, images, videos and rumors that evoke chaos and problems in addition to violating the privacy of others. Such actions may serve the interest of a certain group at the expense of the public interest for the human societies. The study problem was represented in the following questions:

1- What are the most used social media networks among the young people in the Jordanian society from the perspective of the students of the Jordanian universities?

2- What is the role of social media networks in committing the criminal behavior among the young people from the perspective of the students of the Jordanian universities?

3- Are there statistically significant differences at ( $\alpha \leq 0.05)$ regarding the role of social media networks in committing the criminal behavior among the young people in the Jordanian society from the perspective of the students of the Jordanian universities due to the variables of (gender, age, income, educational level, faculty)?

\subsection{The Study Importance}

First: the importance in terms of the theoretical domain:

The study importance lies in being as one of the few studies in the Jordanian society. This study would support the Jordanian and the Arabic libraries with further data about the role of social media networks in committing the criminal behavior by the young people. The results of the current study would be effective in the domain related to educating people about the risks of social media networks on the individual and the family as well as suggesting methods, strategies and policies to prevent the dangerous consequences of social media networks.

Second: the importance at the practical level:

The importance of this study lies inbeing as a scientific support for those interested in studying the role of social media networks in committing the criminal behavior among the young people. The current study may also help those working in the security and educational institutions to identify the role of social media networks in committing the criminal behavior, in addition to its role in helping the decision makers to face the risks of those networks.

\subsection{The Study Objectives}

This study aimed at:

1- Identifying the most commonly used social media networks among the young people in the Jordanian society from the perspective of the students of the Jordanian universities.

2- Identifying the role of social media networks in committing the criminal behavior 
among the young people in the Jordanian society from the perspective of the students of the Jordanian universities.

3- Identifying whether there are statistically significant differences at $(\alpha \leq 0.05)$ regarding the role of social media networks in committing the criminal behavior among the young people in the Jordanian society from the perspective of the students of the Jordanian universities attributed to the variables of( gender, age, income, educational level, faculty).

\subsection{The Study Terminology and Procedural Concepts}

The social media networks: they area number of sites on the internet that enable users to communicate in a virtual society between the individuals participating in the social media sites via the internet, where those participating in these sites have common interests and a certain affiliation to a specific groups. Those individuals communicate by messages, viewing the personal files or each other and recognizing their latest news.It is a method for communication between individuals, whether they were realor unknown via the virtual contexts related to those networks (Boyd and Ellison, 2009).

The social media networks are also defined as the process of communicating with a number of individuals (relatives, colleagues and friends) via the electronic services and sites that provide a high speed in transmitting information in a wide range. Those sites not only provide information, but also coincide and interact with the individual who receives the information during the process of giving that information within the range of the network. As such, they are seen as a method for exchanging information immediately via the internet (Al-Miqdadi 2013).

They are procedurally defined as the electronic networks that enable communicating with others using the audio, video and written words via (Facebook, Twitter and Whats App).

The behavior linguistically: it is derived from the stem "behave". It also refers to going through a certain road or is directed to go through a certain road (IbnManthour, $1414 \mathrm{H}$ ).

The behavior is conceptually defined as the actions that the individual does in his life and society ( Rabie' et al, 2004).

- The criminal behavior: it represents the anti-social behaviors that is directed against the public interest. It is also defined as the opposition of the ethical criteria that are accepted in a certain society and punished by law (Rabie' et al, 2004).

- The youth: it is defined as the stage of power in the human life; it is determined between the years (15-30) of the human life duration (Al-Soofi, 2004).

\section{First: The Theoretical Framework:}

\subsection{The Social Media Networks}

The social media networks are used by millions of people and have an effective role in guiding individuals without consideration to place and time. They enable the opportunities of communication and exchanging information in all the political, social, cultural, economic and 
religious domains that serve the public interests of the human societies. However, some websites may have dangerous consequences to the individual, family and society that are represented by tempting the youth and misleading them. They are used as a tool for exploitation as well as evoking the ethnicity and racism (Scherer, 2012).

There has been a widespread in the social media networks that are based on using the internet for the purposes of establishing relationships, exchanging ideas and opinions throughout the world, such as the network of (Net), (Communication) and (Link). The most important social media networks that have been designed as web pages include (Facebook, Twitter, and WhatsApp ), where the users can communicate with others using the audio, video and written word. They can access the information and files from all over the world. Despite their positive advantages, they have harmful disadvantages against the individual, family and society. Their role can't be overlooked in relation to committing the criminal behavior, such as offences, extremism and terrorism (Al-Faqeeh, 2017).

\subsection{The Most Important Social Media Networks}

The most important social media networks are (Facebook, Twitter, and WhatsApp), detailed as follows:

1- Facebook: Facebookwas founded in 2004. It is considered as one of the most important social media sites, which offers free services, where the individuals subscribe in the site and start using the services provided by the network; they can communicate with others, add friends, send messages and a private file can be created for each user containing his/ her personal information and image. The user can exchange images and publish them on his/ her own page, so that his/ her friends can see them and give their comments about them (O'keeffe and Clarke, 2012).

2- Twitter: it was founded in 2004. It is the second most popular social media site. The users should subscribe and register their data in the network in order to become able to document what they want through a tweet, which is no more than (140) letters (Pooran.2012).

3- WhatsApp: it is one of the most important social media sites that are widely spread due to the great development in the techniques of smart phones; via this technology, the users can send and receive videos, images, text messages through the technology of internet throughout the world. This application is also characterized by clarity and simplicity of using, the high speed in communication as well as the low financial cost (ZephoraInc, 2015).

\subsection{The Characteristics of Social Media Networks}

The social media networks are characterized by several characteristics, including interactivity, exchanging opinions, ideas and attitudes, asynchronization, as well as the motion and universal flexibility, represented by surpassing the borders of time and place as well as the ability to 
make communication between the interaction systems in order to transmit files, images, videos and drawings with the potentialof converting from one form to another (Al-Maliki, 2012).

The social media networks are considered as modern technological methods in the world of communication between individuals. They are characterized by (Al-Daghir, 2013):

1-Universality; they facilitate the processes of communication between individuals and eliminate the borders of time and place.

2- Interaction: the social media networks are considered as an effective method for communication between individuals and institutions.

3-Multi-media advertising method:these networks include the mediators of sound, images, videos which have a social and political effect.

4- Free services: the social media networks save money, time and effort, since the subscription and registration are free.

5- Absolute freedom: the social media networks contribute to promoting the level of freedom of expression as well as obtaining information.

6- The simplicity of usage: using the social media sites doesn't need experience, it only requires the name, password as well as accepting the membership terms.

\section{The Social Media Networks that Have an Impact on Committingthe Criminal Behavior}

The most important social media sites that have an impact on committing the criminal behavior (Al-Baqmi, 2009):

First: the advocate and support sites:

They are the sites which are designed by individuals, organizations or by religious or political institutions in order to disseminate misleading ideas which would, in turn, affect individuals or countries. Such sites could also be used in order to disseminate ideas that are opposing to the system that is governing the country, or could be directed against the social and religious values of the society. The risks of these sites are represented by being a source of rumors as well as misleading those who have a limited range of public knowledge (Al-Baqmi, 2009).

Second: the sites of rejecting thought:

They are sites that disseminate delinquent misleading ideas, in an attempt to distort the image of the country or its doctrine. This is evident within the rejecting thought which calls for distorting the Islamic religion as well as violating others' blood away from the good principles and ethics (Bawadi, 2006).

Third: the sites of extremist thought:

These sites deal with the surface manifestation of religious contexts without realizing the real meaning and intention of them. The individual could reach to an extremist extent in 
misunderstanding religion. Extremism and terrorism are two faces for one coin, in that the extremist individual turns out to be a terrorist. The extremist, at first, adopts a tough situation regarding the doctrine in the face of the changing circumstances that require flexibility in interpretation and application; it also entails the existence of an opposing direction to a real opponent that exists either in fiction or reality. The situation of extremism usually starts by a state of alienation that is based on issuing individual judgments against the society, as they are non-believers, then the individual turns out to using violence against others (Bodour, 2016).

Fourth: The terrorist websites:

Thesesites are considered as the most important methods that contribute to the planning for the terrorist attacks and implementing them throughout the world for several reasons. These sitesare characterized by the high speed in transmitting information, anonymous identity, the speed in creating alternative sites in case the main website was discovered and closing it, the possibility of making the processes of money transfer in order to fund terrorism more quickly, providing the methods of direct chatting between the different sites in different countries, as well as promoting their ideas and the possibility of live transmission in any place all over the world (Al-Baqmi, 2009).

Fifth: The porn sites:

The experts in the security of information and networks suggested that surfing the porn sites is considered as the most favorite method for hackers in committing their electronic crimes. Via these websites, they can collect as much data as possible about the organizations or companies they target in their violations for the interest of certain opposing parties inside or outside the country. Also, the hackers and the enemy intelligence agencies can make advantage of this technology in achieving what they hope, especially in the chatting rooms, which are considered as an important site for collecting personal data and work secrets that some people may imagine them to be useless, while the hackers can use them in violating the networks of sensitive agencies (Al-Baqmi, 2009).

\section{The Role of Social Media Networks in Committing the Criminal Behavior}

The multi-faced negative effects for the social media networks affected the individual, the family and the society by disseminating thebad ideas without being controlled with any limits, as well as devastating the human societies by publishing the ethical and behavioral delinquencies along with the emergence of the extremist though. Those sites also threaten the societal culture, exploit individuals, lead to a state of cultural alienation, in addition to the ideological and intellectual thoughtdistortion that represents a case, in which the individual hasthe feeling of alienation from the society. These sites also aimto distort religion. They promote terrorism and extremism, affiliation to the extremist groups, isolation, weakness in the intellectual abilities for their users, time- wasting, recruiting the young people in those terrorist and extremist groups, promoting the anti-social behaviors as well as devastating the ethical system and destroying the societal values (Al-Obeid, 2006).

3. The theories explaining the role of social media networks in committing the criminal behavior: 
- The Routine Activities Theory:

This theory suggests that in order to represent the routine activities and crime against the individuals or properties, there should be, at the same time and place, a stimulation for the perpetrator as well as a victim. The occurrence of the critical behavior could be easy if there were other conditions or individuals in the situation that encourage the occurrence of that criminal behavior. The criminal behavior could be stopped if the expected victim or another person in the position could do an action that may prevent its occurrence.

Marcus Felson and Lawrence E. Cohen identified three variables that increase or decrease the possibility of the individuals to become victims of direct communication, whether the criminal behavior was against individuals or properties:

1- The offender who has the motivation.

2- The appropriate objective or a serious reason that is worth committing the crime.

3- The qualified keeper for people and properties.

The possibility of committing the criminal behavior increases if there is one or more individuals who have the motivation to commit the crime, and if there is an appropriate objective or a possible victim, or if the official or non-official guards who can stop the process of committing the crime are absent.

The temporal and spatialorganization for the legal routine activities plays an important role in determiningthe pattern, site and amount of illegal actions in terms of law; these actions take place in the local society and the international society as well (AL-Badaineh, et al, 2013).

- Hirsch social bonding theory:

Hirsch's Social Bonding Theorystarts by the general saying stating that "the delinquent actions result when the social bonding between individuals are weak". The theory also suggests that there are four main principles that form this relationship; these are; attachment, commitment, involvement and beliefs(AL-Badaineh, et al, 2013, 171-173).

When the elements ofsocial bonding are strong with parents, adolescents, teachers and peers, the individual's behavior will be inclined towards discipline. On the contrary, whenthese elements are weak, the individual will disrespect law, and according to Hirsch, he will look at them as closely related; if one element is weak, then the other element could also become weak:

1- Attachment to others: this concept refers to the extent of our closed emotional relationships with other individuals as well as being excited and identified with them; therefore, we care about their expectations, in that when we are less sensitive to others' opinions, we will be less committed to the customs that we share with them, and thus those customs will likely be violated.

2-Commitment: it means the extent to which the individual can be related or adjusted to customs and traditions, or his/ herparticipation with adjustment 
which could be exposed to danger or get lost through his/ her involvement in violating law or other forms of delinquency.

3-Involvement: this concept means the degree of the individual's involvement in the cultural activities, such as studying, spending time with the family and sharing in additional activities. Involvement prevents the individual from participating in the delinquent behavior due to the occupied free time.

4-Beliefs: it means acknowledging the traditional values and customs, especially with regard to believing that the rituals and customs of the society are valid and should be followed. This concept doesn't necessarily refer to the beliefsabout certain laws and actions. It doesn't also mean that people keep the delinquent beliefs that urge them to commit the crime. Indeed, Hirsch states that if the beliefs exist among the delinquent individuals, then nothing should be interpreted except for the reason why individuals violate the rules and laws that they actually believe in. Hirsch suggests that their confidence with the ethical validity of laws and rules has become low, and that when the individual believes that rules should be obeyed, he will be more likely to violate them.

\section{- Containment Theory:}

Containment theory is based on the concept of internal and external surveillance itself, referred to as inner and outer containment. The theory of Reckless includes the factors leading the individuals to commit the delinquent actions, such as "pushes" and "pulls" towards delinquency.

The main hypothesis in the containment theory is that the inner or outer factors will lead to the delinquent behaviorunless they are tackled by the inner and outer containment.

When the pushes are directed towards strong delinquencies, and the containment is weak, then the occurrence of the crime is expected. The outer containment includes the supervision, school and family discipline as well as the strong cohesion with the group and the stable ethicalstandards, whereas the inner containment consists mainly from the solid consciousness or the valid concept, which makes the individual less exposed to the pushes and pulls in the delinquent environment (AL-Badaineh, et al, 2013, p. 168).

- The previous studies:

(Al-Faqeeh, 2017) conducted a study entitled by "the role of social media networks in providing the Arab youth with the information and news about the phenomenon of terrorism". The study was conducted on the young people in four Arab countries (the kingdom of Saudi Arabia, Yemen, Egypt and Jordan). The researcher used the snowball samples in order to reach the young people. The data were collected using the electronic questionnaire, where the researcher sent the electronic messages to the study sample individuals via Facebook and Whats App. The results showed that the cognitive effects were in the highest level regarding the effects of the youth dependence on the social media networks as a source of information 
about the phenomenon of terrorism, followed by the emotional effects, then the behavioral effects. The majority of the young people suggested that the social media networks helped the terrorist groups to communicate with a wide range of advocates easily, and facilitated the recruitment of new members in the terrorist groups, in addition to enhancing the size and power of the terrorist groups. There was a positive relationship between the degree of dependence on the social media networks as a source for the information and the factors affecting the information that are related to the phenomenon of terrorism. The results showed that there are statistically significant differences regarding the effects of the young people's independence on the social media networks in order to get information about the phenomenon of terrorism and the affiliation related to the difference in the nationality of the youth.

(Kheliawi, 2017) conducted a study entitled by "the psychological disorders related to using the social media networks among the university students". The study was applied to a random sample from the university of Shaqra' with a total of (210) students who were distributed to four faculties in the governorate of Shaqra;their age ranged between (20-22) years old. The results showed that there is amisuse for the social media networks and that there is a positive relationship between using the social media networks and each of (depression, anxiety and introversion) among the students of the university. The results also revealed that it is possible to predict the state of students, whether they suffered from some psychological disorders (depression, anxiety and introversion) in the light of their usage for the social media networks. The study sample also showed that there are statistically significant differences at $(0.01)$ or less between the male and female students in terms of suffering from anxiety and using the social media networks in favor of the male students.

(Bodour, 2016) conducted a study entitled by " the negative effects for the modern communication techniques on the Muslim family and the role of educating women about the safe uses of this technology and highlighting the phenomenon of the prevalent use of modern communication methods". The results showed that despite the positive effects of the modern communication techniques, they also have negative economic effects related to the prevalence of the consuming culture, adding more financial burden to the family as well as their negative impact on ethics related to disseminating porn and sexual content and the possibility of taking photos and videos for people without their previous knowledge about that. There are also many social effects, including the frigidity in the family relationship; a state that threatens the stability and cohesion of the family, in addition to the psychological and social alienation among the family individuals due to the decline in communication among them as well as the poor social relationships.

(Al-Dolaimi, 2016) conducted a study entitled by "therole of social media networks in shaping the political awareness, a field study for the state of people motion in Iraq". The study sample consisted of the university students in Mousil and Al-Anbar. The study results showed that the social media networks (F, T, Y) contributed toshaping the political trends and raising contemporary issues that attract the university students, especially those related to affecting the political thought and behaviour among the university students as well as the reflection of that on the Iraqi street. The first rank was for Facebook with a percentage of using that reached $(75.5 \%)$ of the university students; which is the most used technology, followed by the 
Youtube, while the last rank was for Twitter due to the lack of using this site. The results also revealed that about $(80 \%)$ of the sample individuals are convinced that the social media networks represented a major reason forsome changes at the Arabic political level. Later on, they played an important role in increasing the political awarenessamong the Iraqi people. The results showed that about (59\%) of the sample individuals were convinced that the eventsexperienced by the Arab countries was closely related to their participation in thesocial media networks, believing that their participation in these sites would promote their political awareness, and that they represented the only democratic mechanism that can change the path of the political process in Iraq towards the best.

(Al-Motairi, 2014) conducted a study which aimed at identifying the role of social media networks in the behavioural delinquency among the university students from the perspective of the students of the Jordanian universities. The study sample consisted of (1090) male and female students. The results showed that the most favourite social media networks among the study sample individuals were Facebook, Whats App and Twitter, respectively, and that the most used devices are the smart phones, as well as the tablets. The results revealed that the best place for communication was the university, the best time was the evening for less than two hours a day and that they spent less than five dinars a week for communication. Most of the students suggested thatthe social media networks contributed to the behavioural delinquency among the students and that the most influential site was the Facebook followed by YouTube, and then Whats App. The results revealed that the role of social media networks in committing the delinquent behaviour was medium and that the risks related to using the social media networks were high.

(Mansour, 2012) conducted a study which aimed at identifying the usage of the Jordanian young people to the social media networks and the role of them in satisfying their needs as well as identifying the needs and desires that the Jordanian young people achieve from using the social media networks. The study sample consisted of (286) male and female students. The results showed that there is a high percentage of using the social media networks among the Jordanian young people with a percentage of $(93.7 \%)$. Facebook was in the first rank with regard to using the social media networks with a percentage of $(72.4 \%)$ among the sample individuals in comparison with the other social media networks and that the young people use the social media networks for a period that ranged between one to two hours a day with a general percentage of (38.1\%). The results revealed that the general place for using the social media networks is the house with a percentage of (86.4\%)and that the satisfied needs achieved by the Jordanian university youth from using the social media networks ordered according to the priorities of using them were as follows: cognitive needs, emotional needs, pragmatic personal needs, social needs as well as the needs related to escaping from the reality and filling the free time.

- Foreign studies:

(Shatlat, 2017) conducted a study which aimed at identifying the prevalence ofrumours in the social media networksand their role in creating political violence and conflict among the university youth. The researcher used the social survey method . The study was applied to (400) 
individuals from four different Egyptian groups, including the university of Kafir Al-Sheikh, the university of Al-Azhar, the university of 6 October and the American university in Cairo. The study results showed that Facebook was the most used and preferred social media network among the students of the universities, while the other social media networks, such as Whats App and YouTube were in the second and third ranks respectively. The communication with friends and family members was the most important reason that urged the university students to surf the social media networks, followed by the desire to use up their free time, the desire to surf the social network pages, as well as sharing and writing comments. The most important objective of disseminating rumours through the social media networks is promoting violence and political conflict within the society, which was in the first rank, followed bythe disintegration of the society unit in the second place, creating a state of mess and chaos among the members of the society, while devastating the values and peace of the society were in the last rank. The results showed that about (65.5\%)of the respondents stated that the rumoursthat are disseminated through the social media networks led to conflict and political violence, while $(65 \%)$ suggested that the rumours disseminated via the social media networks led to the political movements in many Arab countries, known as the revolutions of Arabic spring. About $(61.3 \%)$ stated that the rumours disseminated via the social media networks were related toindicating to the political decisions, while (57.9\%) suggested that the disseminated rumours represented a confusion in the country.

(Jones, Baldwin \& Lewis, 2014) conducted a study entitled by " the role of social media networks in committing the sexual crimes" . The study aimed at identifying the role played by the social media networks in facilitating the process of committing crimes, as well as the ability of using them in order to educate the young people toreduce committing the sexual crimes.In order to achieve the study objectives, the researcher used the descriptive survey approach and the questionnaire was used as the study instrument. The study sample consisted of (896) students from the university students in the USA, whose age rangedbetween (17-24) years old. The results showed that about (2.84\%) of the students suggested that the social media networks facilitated practicing sexual crimes, and (10\%) confirmed that they had illegal sexual relationships related to using the social media network. The study results concluded thatthe social media networks could be an effective mechanism for disseminating information and enhancing the positive behavioural changes among the young people by promoting the educational materials as well as instructions about the possible crimes and risks of using them.

(Virden, Trujillo and Predeger, 2014) conducted a study entitled by "the risks of using social media networks from the perspective of the female youth". In order to achieve the study objectives, the researcher used the qualitative approach as well as the interview as the study instrument. The study sample consisted of (14) female university students in the state of California . The study results showed that the female students confirmed that the social media networks have an important role incommitting the delinquent behavior, in that they facilitate the establishment of illegal relationships, exploitation, sexual assaults as well as abusing adolescents and children.

(Girond, 2013) conducted a study entitled by " the relationship between the social media networks (Facebook, Twitter) and the anti-social behaviors in the universities of the south-east 
of the United States of America". The study aimed to identifythe relationship between the social media networks and the anti-social behaviors. The study sample consisted of (467) individuals. The researcher used the questionnaire as a tool for data collection. The results showed that there is a positive relationship between using the social media networks (Facebook, Twitter) and the delinquentbehavior, in that the delinquent behavior increases with the increased use of social media networks.

(Young, Szekeres, and Coates, 2013) conducted a study entitled by " the relationship betweenusing the social media networks (Facebook, Twitter) and the sexual delinquency in the United States of America". The study sample consisted of (122) participants. The study results showed that there is a positive relationship between using the social media networks and the sexual delinquency, in that the social media networks facilitate the processes ofmeeting and making friendships between those who have the desire to practice the delinquent behavior in order to get food, drugs or a place of residence.

(Muise, Christofides and Desmarais,2009) conducteda study entitled by " Information more than you may need, jealousy between partners" in order to detect the role of Facebook in evoking jealousy and envy between partners aswell as the impact of the intensive use of the social media networks and whether they predictthe relationships that are based on jealousy and doubt. The study sample consisted of (308) bachelor degree students whose age ranged between (17-24)years old. The results showed that theextensive use of Facebook leads to jealousy and envydue to the addiction that may lead to knowing more information about the partner which could be ambiguous and not easily accessible. Theresults showed that the majority of the respondents spent about (40) minutes using Facebook each day, and that the females used Facebook more than males with about (25-1000) friends for each girl.The results showed that about $(74.6 \%)$ of the sample individuals added their friends with whom they had emotional or sexual relationship in the past and that $(92.1 \%)$ of the respondents' partners had stranger friends that they didn't know in the real world which, in turn, evoked jealousy and envy among partners.

- The study methodology:

What distinguishes the current study from the previous studies is its attempt to identify the role of social media networks in committing the criminal behavior among the young people in the Jordanian society from the perspective of the students of the Jordanian universities. This study used the social survey which included the ready office survey in order to construct the theoretical framework for the study, in addition to using the field survey for collecting the data using the study instrument as well as analyzing it statistically in order to answer the study questions.

- The study population:

The study population consisted of all the students of the Jordanian universities in three regions: the middle region ( the university of Jordan), the north region ( Al-Yarmouk university), and the south region ( Al-Hussein IbnTalal university) for the bachelor degree students enrolled in the academic year (2018/2019). 
- The study sample:

The study sample was chosen in the simple random way from the various specialties and courses in the Jordanian universities, with an average of (4) courses from each university. The study questionnaire was distributed to a sample that consisted of (595) male and female students from those universities, as shown in table (1):

Table 1 . The distribution of the study sample according to the university

\begin{tabular}{lll}
\hline University & Number of students & Percentage \\
\hline Jordan & 215 & $36.13 \%$ \\
Al-Yarmouk & 205 & $34.45 \%$ \\
Al-Hussein IbnTalal & 175 & $29.41 \%$ \\
Total & 595 & $100 \%$ \\
\hline
\end{tabular}

- The study instrument:

In order to achieve the study objectives, the researcher developed a questionnaire to study the role of social media networks in committing the criminal behavior among the young people in the Jordanian society from the perspective of the students of the Jordanian universities. The questionnaire was developed based on previous studies, such as Al-Faqeeh, 2017, Al-Motairi, 2014 ,Bodour, 2016, Al-Dolaimi, 2016. The study instrument was developed based on the 5-pointLikert scale.

- The study instrument consisted of two parts:

The first part: it includes the demographic variables for the study sample ( gender, age, monthly income, educational level, faculty) and was measured with the items that ranged between (1-5).

The second part: the most used social media networks among the young people in the Jordanian society from the perspective of the students of the Jordanian universities, referred to in the items (6-8).

The third part: the role of social media networks in committing the criminal behavior among the young people in the Jordanian society from the perspective of the students of the Jordanian universities, measured by the items (9-34).

In order to identify the role of social media networks in committing the criminal behavior among the young people in the Jordanian society from the perspective of the students of the Jordanian universities, the means and standard deviations were calculatedand the scaling used in the study was as follows: 


\begin{tabular}{|l|l|l|l|l|}
\hline Always applies & Often applies & $\begin{array}{l}\text { Sometimes } \\
\text { applies }\end{array}$ & Rarely applies & Never applies \\
\hline$(1)$ & $(2)$ & $(3)$ & $(4)$ & $(5)$ \\
\hline
\end{tabular}

Based on that, the calculated means of the study will be used in order to explain the data as follows:

\begin{tabular}{|l|l|l|}
\hline High & Medium & Low \\
\hline 3.5 or more & $2.5-3.49$ & $1-2.49$ \\
\hline
\end{tabular}

Based on that, if the mean value for the items is more than (3.5), then the evaluation level is high, which means that the sample individuals agree on the item, if the value of the mean ranges between (2.5-3.49), then the evaluation level is medium, while the mean that is less than (2.49) indicates a low level of evaluation.

- The study instrument validity:

In order to verify the validity of the study instrument, it was introduced to (6) arbitrators of those who have experience and specialized in the specialties of criminology, sociology, psychology, educational measurement, and educational sciences in the Jordanian universities. The researcher adopted an agreement percentage of (86\%) among the committee of the arbitrators. In the light of that, the arbitrators' opinions were taken into consideration, and the necessary modification were done, represented by paraphrasing some items

- The study reliability:

The study reliability was verified by calculating (Cronbach Alpha), using the statistical package (SPSS), where the value of Cronbach Alpha was (0.86).

Based on the results of validity and reliability of the study instrument, it is clear that the study instrument is applicable to the current study.

- The used statistical methods:

The researcher used a number of statistical methods in order to answer the study questions, using (SPSS), including:

1- The Descriptive Statistic Measures, they are used to describe the characteristics of the study sample, based on the frequencies and percentages, in addition to answering the study questions as well as identifying the relative importance by sing the means and the standard deviations. 
2- Pearson correlation coefficient: it was used to test the correlation relationships between the study variables.

3- One way ANOVA.

- The characteristics of the study sample:

Based on the results of table (2) relating to the characteristics of the study sample, it is evident that about $(51.3 \%)$ of the study sample individuals are males, while $(48.7 \%)$ are females, indicating the approximation between the percentages related to gender. The results revealed that those who are (20) years old or less gained the highest percentage with about $(48.4 \%)$, followed by those whose age ranged between (21-22) years old, with about (29.4\%), then those whose ranged between (25-29) years old, with a percentage of (14.6\%), while the least percentage was for those ( more than 30 years old), with a percentage of $(7.56 \%)$. The results revealed that those whose monthly income ranged between (301- 400) JD were about $(27.7 \%)$, followed by those whose monthly income is less than (300) JD, with a percentage of $(21 \%)$, then those whose monthly income ranged between (501-600) JD, with a percentage of (19.3\%). The individuals whose monthly income ranged between (401-500) JD, were about (17.4\%), while those whose monthly income is more than (600) JD, were about (14.04\%). The educational qualification for the study sample individuals in the first year was about $(25 \%)$, followed by the second year with about $(24.2 \%)$, then the third year with a percentage of $(22.1 \%)$. The fourth year gained a percentage of $(17.4 \%)$ and finally the fifth year with about $(11 \%)$. As for the variable of faculty, the humanitarian faculties had a percentage of $(49.4 \%)$ while the scientific faculties had a percentage of (50.6\%).

Table 2. The distribution of the study sample according to the demographic variables

\begin{tabular}{|l|l|l|l|}
\hline Variable & Categories & Number & Percentage \\
\hline \multirow{4}{*}{ Gender } & Male & 305 & $51.3 \%$ \\
\cline { 2 - 4 } & Female & 290 & $48.7 \%$ \\
\cline { 2 - 4 } & Total & 595 & $100 \%$ \\
\hline \multirow{5}{*}{ Age } & Less than 20 & 288 & $48.4 \%$ \\
\cline { 2 - 4 } & $21-24$ & 175 & $29.4 \%$ \\
\cline { 2 - 4 } & $25-29$ & 87 & $14.6 \%$ \\
\cline { 2 - 4 } & More than 30 & 45 & $7.56 \%$ \\
\cline { 2 - 4 } & Total & 595 & $100 \%$ \\
\hline & Less than 300 & 125 & $21.0 \%$ \\
\cline { 2 - 4 } & $301-400$ & 165 & $27.7 \%$ \\
\hline
\end{tabular}




\begin{tabular}{|l|l|l|l|}
\hline \multirow{4}{*}{} & $401-500$ & 104 & $17.4 \%$ \\
\cline { 2 - 4 } & $501-600$ & 115 & $19.3 \%$ \\
\cline { 2 - 4 } & More than 600 JD & 86 & $14.4 \%$ \\
\cline { 2 - 4 } & Total & 595 & $100 \%$ \\
\hline \multirow{5}{*}{ Educational level } & First & 149 & $25.0 \%$ \\
\cline { 2 - 4 } & Second & 144 & $24.2 \%$ \\
\cline { 2 - 4 } & Third & 132 & $22.1 \%$ \\
\cline { 2 - 4 } & Fourth & 104 & $17.4 \%$ \\
\cline { 2 - 4 } & Fifth & 66 & $11.0 \%$ \\
\cline { 2 - 4 } & Total & 595 & $100 \%$ \\
\hline & Humanitarian & 294 & $59.4 \%$ \\
\cline { 2 - 4 } & Scientific & 301 & $100 \%$ \\
\cline { 2 - 4 } & Total & 595 & \\
\hline
\end{tabular}

- The results:

1- The first question: What are the most used social media networks among the young people in the Jordanian society from the perspective of the students of the Jordanian universities?

In order to answer this question, the frequencies and the relative importance for the most used social media networks among the young people were calculated, as shown in table (3).

Table 3. The relative distribution for the most used social media networks among the young people in the Jordanian society from the perspective of the students of the Jordanian universities

\begin{tabular}{|l|l|l|l|}
\hline Rank & Social media site & Frequency & Percentage \\
\hline 1 & Facebook & 405 & $68.0 \%$ \\
\hline 2 & Whats App & 150 & $25.2 \%$ \\
\hline 3 & Twitter & 40 & $6.7 \%$ \\
\hline Total & 595 & $100 \%$ \\
\hline
\end{tabular}


The results of Table (3) showed that the most used social media network among the young peoplewas Facebook in the first place, with a percentage of $(68 \%)$, followed by Whats App with a percentage of $(25.2 \%)$, while Twitter was in the third place with a percentage of $(6.7 \%)$.

- The second question: What is the role of social media networks in committing the criminal behavior among the young people in the Jordanian society from the perspective of the students of the Jordanian universities?

In order to answer this question, the means and standard deviations were calculated for the study sample individuals for each item of the items of this domain, table (4).

Table 4. The means and standard deviations for the role of social media networks in committing the criminal behavior among the young people in the Jordanian society from the perspective of the students of the Jordanian universities

\begin{tabular}{|l|l|l|l|l|}
\hline Item & Mean & $\begin{array}{l}\text { Standard } \\
\text { deviation }\end{array}$ & Rank & Degree \\
\hline $\begin{array}{l}\text { Stealing the personal data and violating the } \\
\text { privacy of others. }\end{array}$ & 4.11 & 0.75 & 1 & High \\
\hline $\begin{array}{l}\text { Tempting and attracting the young people to } \\
\text { join extremist and terrorist groups }\end{array}$ & 4.09 & 0.74 & 2 & High \\
\hline $\begin{array}{l}\text { Disseminating rumors, defaming others and } \\
\text { harming them. }\end{array}$ & 4.01 & 0.66 & 3 & High \\
\hline $\begin{array}{l}\text { Sending harmful and insulting messages as } \\
\text { well as harassing others feelings. }\end{array}$ & 4.00 & 1.02 & 4 & High \\
\hline $\begin{array}{l}\text { Verbal abuse, cursing and slandering others. } \\
\text { Introversion between young people and the } \\
\text { feeling of anxiety, stress, depression and } \\
\text { alienation. }\end{array}$ & 3.97 & 0.74 & 6 & High \\
\hline $\begin{array}{l}\text { Disseminating the personal photos and } \\
\text { videos that violate the public morals as well } \\
\text { as taking photos of individuals without their } \\
\text { knowledge. }\end{array}$ & 3.96 & 0.72 & 5 & High \\
\hline $\begin{array}{l}\text { Devastating the social relationships } \\
\text { Disseminating the ideas that insult religions. }\end{array}$ & 3.88 & 0.79 & 9 & High \\
\hline $\begin{array}{l}\text { Sending the statements of hatred and envy to } \\
\text { others. }\end{array}$ & 3.85 & 1.01 & 10 & High \\
\hline
\end{tabular}




\begin{tabular}{|c|c|c|c|c|}
\hline $\begin{array}{l}\text { Gaining the fake friendships for the } \\
\text { purposes of exploitation. }\end{array}$ & 3.83 & 1.04 & 11 & High \\
\hline Disseminating false rumors & 3.81 & 0.76 & 12 & High \\
\hline $\begin{array}{l}\text { A method for threatening others and abusing } \\
\text { them }\end{array}$ & 3.80 & 0.75 & 13 & High \\
\hline $\begin{array}{l}\text { Disseminating harmful messages that may } \\
\text { lead to suicide. }\end{array}$ & 3.79 & 0.90 & 14 & High \\
\hline The poor family relationships & 3.78 & 0.78 & 15 & High \\
\hline $\begin{array}{l}\text { Facilitating fraud and cyber cheating (fake } \\
\text { buying and selling). }\end{array}$ & 3.75 & 0.79 & 16 & High \\
\hline $\begin{array}{l}\text { Exploiting local events and news to provoke } \\
\text { conflicts. }\end{array}$ & 3.74 & 0.72 & 17 & High \\
\hline $\begin{array}{l}\text { Mobilizing people to hate the political } \\
\text { system. }\end{array}$ & 3.72 & 0.71 & 18 & High \\
\hline $\begin{array}{l}\text { Encouraging the process of committing the } \\
\text { violent behaviors }\end{array}$ & 3.70 & 0.75 & 19 & High \\
\hline $\begin{array}{l}\text { Sexual harassment and annoying females } \\
\text { through chatting and conversation. }\end{array}$ & 3.69 & 0.80 & 20 & High \\
\hline $\begin{array}{l}\text { Disturbing social relationships between the } \\
\text { individual, his family and community. }\end{array}$ & 3.68 & 0.82 & 21 & High \\
\hline $\begin{array}{l}\text { Promoting the principles of suspicious } \\
\text { groups at a broader level. }\end{array}$ & 3.65 & 0.79 & 22 & High \\
\hline $\begin{array}{l}\text { Inciting and interfering with the interests of } \\
\text { others. }\end{array}$ & 3.63 & 0.67 & 23 & High \\
\hline $\begin{array}{l}\text { Disseminating the ideas of racism at the } \\
\text { community level. }\end{array}$ & 3.62 & 1.05 & 24 & High \\
\hline $\begin{array}{l}\text { Inciting the participation in chaos and } \\
\text { rebellious actions. }\end{array}$ & 3.60 & 0.89 & 25 & High \\
\hline Average & 3.82 & 0.80 & \multicolumn{2}{|c|}{ High } \\
\hline
\end{tabular}

The results in Table (4) showed that the means for the role of social media networks in committing the criminal behavior among the young people in the Jordanian society from the perspective of the students of the Jordanian universities were high in general, where the mean was (3.82) with a standard deviation of (0.81). The first rank was for stealing personal data and 
violating the privacy of others, with a mean of (4.11)and a standard deviation of (0.75), followed by" tempting the young people to join the terrorist and extremist groups", with a mean of (4.09) and a standard deviation of (0.74). The third place was for " Disseminating rumors, defaming others and harming them", with a mean of (4.01) and a standard deviation of (0.66), while the last rank was for "Inciting the participation in chaos and rebellious actions" with a mean of (3.60) and a standard deviation of 0.89 and a medium degree.

The third question:Are there statistically significant differences at $(\alpha \leq 0.05)$ for the role of social media networks in committing the criminal behavior among the young people in the Jordanian society from the perspective of the students of the Jordanian universities due to the variable of gender?

\section{1- Gender:}

In order to detect whether there are differences regarding the mean responses for the study sample individuals towards the role of social media networks in committing the criminal behavior among the young people in the Jordanian society from the perspective of the students of the Jordanian universities due to the variable of gender, (t-test) was conducted for the independent samples, as illustrated in Table (5).

Table 5. (T-test) to test the significance of differences regarding the mean responses for the study sample individuals towards the role of social media networks in committing the criminal behavior among the young people in the Jordanian society from the perspective of the students of the Jordanian universities due to the variable of gender

\begin{tabular}{|l|l|l|l|l|l|l|l|}
\hline Variable & category & Number & Mean & $\begin{array}{l}\text { Standard } \\
\text { deviation }\end{array}$ & $\begin{array}{l}\text { Degree of } \\
\text { freedom }\end{array}$ & T-value & $\begin{array}{l}\text { Sig } \\
\text { level }\end{array}$ \\
\hline \multirow{2}{*}{ Gender } & Male & 305 & 3.88 & 0.88 & 1 & 2.77 & 0.170 \\
\cline { 2 - 7 } & Female & 290 & 3.82 & 0.84 & 594 & & \\
\hline
\end{tabular}

Table (5) showed that there are no statistically significant differencesbetween theresponses for the study sample individuals towards the role of social media networks in committing the criminal behavior among the young people in the Jordanian society from the perspective of the students of the Jordanian universities due to the variable of gender, where (T-value ) was $(0.42)$, which is statistically significant at $(\alpha \leq 0.05)$.

2- Age:

(ANOVA ) was used in order to detect whether there are differences regarding the role of social media networks in committing the criminal behavior among the young people in the Jordanian society from the perspective of the students of the Jordanian universities due to the variable of age, as illustrated in table (6). 


\section{Macrothink}

International Journal of Learning and Development

ISSN 2164-4063 2020, Vol. 10, No. 1

Table 6. The results of analysis of variance to detect thedifferences regarding role of social media networks in committing the criminal behavior among the young people in the Jordanian society from the perspective of the students of the Jordanian universities due to the variable of age

\begin{tabular}{|l|l|l|l|l|l|}
\hline $\begin{array}{l}\text { Source of } \\
\text { variance }\end{array}$ & $\begin{array}{l}\text { Total } \\
\text { squares }\end{array}$ & $\begin{array}{l}\text { Degrees of } \\
\text { freedom }\end{array}$ & Mean squares & f-value & Sig level \\
\hline Intergroup & 2.602 & 3 & 0.732 & \multirow{2}{*}{4.33} & \multirow{2}{*}{0.153} \\
\cline { 1 - 4 } Intragroup & 117.206 & 592 & 0.169 & \\
\cline { 1 - 3 } Total & 119.808 & 595 & & \\
\hline
\end{tabular}

Table 6 showed that there are no statistically significant differencesregarding the role of social media networks in committing the criminal behavior among the young people in the Jordanian society from the perspective of the students of the Jordanian universities due to the variable of age, where the calculated (F-value ) was (4.33), which is statistically significant at $(\alpha \leq 0.05)$.

\section{3- Income:}

(ANOVA ) was used in order to detect whether there are differences regarding the role of social media networks in committing the criminal behavior among the young people in the Jordanian society from the perspective of the students of the Jordanian universities due to the variable of income, as illustrated in Table (7).

Table 7. The results of analysis of variance to detect thedifferences regarding role of social media networks in committing the criminal behavior among the young people in the Jordanian society from the perspective of the students of the Jordanian universities due to the variable of income

\begin{tabular}{|l|l|l|l|l|l|}
\hline $\begin{array}{l}\text { Source of } \\
\text { variance }\end{array}$ & $\begin{array}{l}\text { Total } \\
\text { squares }\end{array}$ & $\begin{array}{l}\text { Degrees of } \\
\text { freedom }\end{array}$ & Mean squares & f-value & Sig level \\
\hline Intergroup & 2.401 & 4 & 0.752 & \multirow{2}{*}{2.77} & \multirow{2}{*}{0.231} \\
\cline { 1 - 4 } Intragroup & 119.216 & 491 & 0.271 & \\
\cline { 1 - 3 } Total & 121.617 & 595 & & \\
\hline
\end{tabular}

The results of Table (7) showed that there are no statistically significant differencesregarding the role of social media networks in committing the criminal behavior among the young people in the Jordanian society from the perspective of the students of the Jordanian universities due to the variable of income, where the calculated (F-value ) was (2.77), which is statistically 


\section{Macrothink}

significant at $(\alpha \leq 0.05)$.

4- Educational level:

(ANOVA) was used in order to detect whether there are differences regarding the role of social media networks in committing the criminal behavior among the young people in the Jordanian society from the perspective of the students of the Jordanian universities due to the variable of educational level, as illustrated in Table (8).

Table 8. The results of analysis of variance to detect thedifferences regarding role of social media networks in committing the criminal behavior among the young people in the Jordanian society from the perspective of the students of the Jordanian universities due to the variable of educational level

\begin{tabular}{|l|l|l|l|l|l|}
\hline Source of variance & $\begin{array}{l}\text { Total } \\
\text { squares }\end{array}$ & $\begin{array}{l}\text { Degrees } \\
\text { freedom }\end{array}$ & $\begin{array}{l}\text { Mean } \\
\text { squares }\end{array}$ & f-value & Sig level \\
\hline Intergroup & 0.185 & 4 & 0.742 & & \\
\cline { 1 - 4 } Intragroup & 121.672 & 491 & 0.221 & 3.35 & 0.015 \\
\hline Total & 211.857 & 595 & & & \\
\hline
\end{tabular}

The results of Table (8) showed that there are no statistically significant differencesregarding the role of social media networks in committing the criminal behavior among the young people in the Jordanian society from the perspective of the students of the Jordanian universities due to the variable of educational level, where the calculated (F-value ) was (3.35), which is statistically significant at $(\alpha \leq 0.05)$.

\section{5- Faculty :}

(ANOVA) was used in order to detect whether there are differences regarding the role of social media networks in committing the criminal behavior among the young people in the Jordanian society from the perspective of the students of the Jordanian universities due to the variable of faculty, as illustrated in Table (9). 
Table 9. The results of analysis of variance to detect thedifferences regarding role of social media networks in committing the criminal behavior among the young people in the Jordanian society from the perspective of the students of the Jordanian universities due to the variable of faculty

\begin{tabular}{|l|l|l|l|l|l|}
\hline $\begin{array}{l}\text { Source of } \\
\text { variance }\end{array}$ & $\begin{array}{l}\text { Total } \\
\text { squares }\end{array}$ & $\begin{array}{l}\text { Degrees of } \\
\text { freedom }\end{array}$ & Mean squares & f-value & Sig level \\
\hline Intergroup & 1.765 & 1 & 0.851 & \multirow{2}{*}{4.947} & \multirow{2}{*}{0.005} \\
\hline Intragroup & 118.172 & 594 & 0.175 & \\
\cline { 1 - 4 } Total & 211.937 & 595 & & \\
\hline
\end{tabular}

The results of table (9) showed that there are no statistically significant differences regarding the role of social media networks in committing the criminal behavior among the young people in the Jordanian society from the perspective of the students of the Jordanian universities due to the variable of faculty, where the calculated (F-value ) was (4.947), which is statistically significant at $(\alpha \leq 0.05)$.

- Discussing the study results:

- Discussing the results of the first question: What are the most used social media networks among the young people in the Jordanian society from the perspective of the students of the Jordanian universities?

The results revealed that the most used social media network among the young people was the Facebook, with a percentage of (68\%), followed by Whats App with a percentage of $(25.2 \%)$, and finally Twitter with a percentage of $(6.7 \%)$.

This finding agrees with (Shatlat, 2017), (Al-Dolaimi, 2016), (Al-Motairi, 2014) and (Mansour, 2012).

- Discussing the results of the second question: What is the role of social media networks among the young people in the Jordanian society from the perspective of the students of the Jordanian universities?

The study results showed that the means for the role of social media networks among the young people in the Jordanian society from the perspective of the students of the Jordanian universities was high, where the mean was (3.82) with a standard deviation (0.81). The first rank was for "stealing personal data and violating the privacy of others", with a mean of (4.11) and a standard deviation of (0.75), followed by" tempting the young people to join the terrorist and extremist groups", with a mean of (4.09) and a standard deviation of (0.74). The third place was for "Disseminating rumors, defaming others and harming them.", with a mean of (4.01) and a standard deviation of (0.66), while the last rank was for "Inciting the participation in chaos and rebellious actions"with a mean of (3.60) and a standard deviation of 0.89 and a medium degree. 
This result matches with (Shatlat, 2017), (Khaliawi, 2017), (Al-Motairi, 2014), (Jones, Baldwin \& Lewis, 2014), (Nemati, Wall \& Chow, 2014) and (Virden, Trujillo \&Predeger, 2014).

The routine activities theory suggests that there should be a time and place, a stimulation for the perpetrator to commit the crime and there should be a victim. The occurrence of the criminal behavior could be easy if there were other conditions or individuals in the situation that would encourage its occurrence, especially via the social media networks through which the offenders can use an unanimous identity that can't be monitored and their electronic source can't be identified easily. The absence of security and societal surveillance as well as the absence of official or non-official guards, who could prevent committing the illegal behaviors via Facebook, Whats App and Twitter, wouldalso encourage committing the criminal behavior.

The theory of Hirsch suggests that when the elements of social bonding are strong with parents, adolescents, teachers and peers, the individual's behavior will be inclined towards discipline. On the contrary, when these elements are weak, the individual will disrespect law, and according to Hirsch, he will look at them as closely related; if one element is weak, then the other element could also become weak.

The containment theory interprets this finding by stating that the push and pull factors will lead the individuals to commit the delinquent actions unless they are faced by the internal and external containment. When the pushes towards delinquency are strong while the containment is weak, then the crime is expected to occur. The outer containment includes the supervision, school and family discipline as well as the strong cohesion with the group.

Discussing the results of the second question: the study results showed that there are no statistically significant differences between the responses of the study sample individuals regarding the role of social media networks among the young people in the Jordanian society from the perspective of the students of the Jordanian universities due to the variables of gender, age, income, educational level and faculty at $(\alpha \leq 0.05)$. This result doesn't agree with (Al-Faqeeh, 2017) and (Al-Khaliawi, 2017).

- Recommendations:

In the light of the results, the study recommended:

1- The necessity of emphasizing the protection of privacy of the social media networks users by the legal legislations.

2- Urging the organizations of the social development ( family, school, , mosques, clubs and youth centers) to hold awareness lectures for the community members about risks of using social networks.

3- Developing the curriculum in order to instill the religious values amongstudentsand avoid negative use of social networks.

4- Urging the media to raise the awareness about the dangers of committing the 


\section{Macrothink}

criminal behaviors via social media networks.

5- Encouraging the security agencies to hold lectures and awareness seminars about the negative uses of social networks.

6- Urging the national Parliament to enact strict laws in order to limit the process of committing criminal behavior via social media networks.

\section{References}

Al-Badayneh, T., \& Al-Khraisheh, R. (2013). Theories of Criminology, Thought House (1st ed.). Amman.

Al-Baqmi, N. M. (2009). The Impact of Changing into an Information Society on Intellectual Security, A research introduced to the First National Conference on Intellectual Security (Concepts and Challenges), during 16-19, 2009 May, Saudi Arabia, p. (18-22).

Al-Daghir, M. M. A. (2013). The Usage of Media Professionals to Social Media Networks and Perverted Rumors, An Applied Study on the Communicator in Media Institutions in Saudi Arabia. Journal of the Faculty of Arts, the University of Zaqaziq, 64, 542.

Al-Dlaimi, A. R. R. M. (2016). The role of social media sites in forming the political awareness "A field study about the state of popular movement in Iraq on a sample of students from the universities of Al-Mosil, Al-Anbar and Tikrit during the period (1/3/2013 1/6/2013). The Journal Studies of the Humanities and Social Sciences, 43(2), 1299-1319.

Al-Kafi, M. A. W. (2017). The Role of Social Media Networks in Providing the Arab Youth with Information and News about the Phenomenon of Terrorism: A Comparative Study among the Youth in Four Arab Countries. The Arab Journal of Media and Communications, 49(17), 273-420.

Al-Mansour, M. (2012). The impact of social media networks on the audience (unpublished Master Thesis, The Arab Open Academy in Denmark, Denmark).

Al-Miqdadi, K. (2013). The social networking revolution ( $1^{\text {st }}$ ed.). Dar Al Nafa'is for Publishing and Distribution: Amman.

Al-Motairi, S. (2014). The role of social media networks in the behavioral deviation among university youth from the perspective of Jordanian university students (unpublished doctoral dissertation, Mu'tah University, Al-Karak, Jordan).

Al-Soofi, H. (2004), An Educational Conceptualization to Face the Dangers of Using the Internet among the Young People, the First Educational Conference, Education in Palestine, and the Changes of the Era (23-24 / 11/2004) (the Islamic University of Gaza, Palestine).

Al-Obeid, M. (2006). Media Terrorism Against the Arab World, Dar Al-Ma'refa (2nd ed., p. 193). Beirut, Lebanon.

Al-Yousif, A. A. (2004). Security is the Responsibility of Everyone: A Future Vision, the third Seminar on Society and Security, King Fahd Security College (2nd ed.). Al-Riyadh, Saudi 
Arabia, p. (787-788).

Badour, H. A. (2016). The Negative Effects of Modern Communication Technologies on the Muslim Family and the Role of Women in Educating her about the Safe Usage. Journal of Al-Quds Open University, 39(2), 305-336.

Bassiouni, A. H. (2003). Protection from the risks of the Internet, the scientific books House. Cairo, Egypt, p. 11.

Bawadi, H. Al-M. (2006). Intellectual Terrorism: Its Causes, Confrontation (the University Thought House, Alexandria, Egypt, p 97).

Faraj, A. L. H. (2004). The task of the Secondary School Manager with regard to the deviant behavior among the young people, from the point of view of high school managers enrolled in the training course at the University of Um Al-Qoura, community and security seminar, King Fahd College.

IbnManthour, the Arab tongue ( Lisan Al-Arab), part 9, Dar Sadir, Beiruit, p.4.

Khaliawi, A. B. F. (2017). Psychological Disorders Associated with the Use of Social Media Sites among University Students. Journal of the Islamic University of Educational and Psychological Studies, 25(4), 41-101.

Mahmoud, K. (2011). Social Media Networks and the Dynamics of Change in the Arab World. Beirut: Madarik Publishing House.

Mansour, T. (2012). The Role of Social Media Networks in satisfying the Needs of Jordanian Youth: A Comparative Study on Gender. The Sixth Annual Saudi Forum for Media and Communication, the New Media: Theoretical and Applied Challenges (the University of King Saud, Al-Riyadh, (14-15) April 2012).

Moustafa, K. (2014). The criminal responsibility for the publishers of technical services regarding the misuse of Social Media Networks (The Faculty of Law, University of Ajman).

Rabi', M. S., Youssef, J. S., \& Abdullah, M. S. (2004), Criminal Psychology, Cairo. Dar Gharib for Printing and Publishing.

Shatlat, M., \& Abdel, H. (2017). Rumors in social networking sites and their role in violence and political conflict among, the Egyptian youth university, A Field Study. Jurnal of Public Relations Research Middle East / Jul-Sep2017, 16, 10-192.

Yousif, S. (2013). Crime committed via the internet. The University of MouloudMa'mari, Algeria.

Boyd, D., \& Ellison, N. (2010). Social Network Sites; Definition, History and Scholarship (Department of Communication, University). https://doi.org/10.1109/EMR.2010.5559139

Gironda, J. (2013). Social Networking Sites And Planned Behavior. Academic Search Complete, Summer Educators' Conference Proceedings, 23, 387-388. 


\section{Macrothink}

International Journal of Learning and Development

ISSN 2164-4063 2020, Vol. 10, No. 1

Jones, K., Baldwin, K. \& Lewis, P. (2014). The Potential Influence of a Social Media Intervention on Risky Sexual Behavior and Chlamydia Incidence. Journal of Community Health Nursing, 29(1), 106-120. https://doi.org/10.1080/07370016.2012.670579

Kietzman, J. H., Herm kens, K., McCarthy, I. P., \& Silvestre, B. S. (2011). "Social media? Get serious! Understanding The functional Building Blocks Of Social Media". Business Horizons, 54(3), 241-251. https://doi.org/10.1016/j.bushor.2011.01.005

Muise, A., Christofides, E., \& Desmarais, S. (2009). More Information than you Ever Wanted: Does Facebook Bring out the Green-Eyed Monster of Jealousy.?, Cyber psychology\& Behavior, 4(12), 441-444. https://doi.org/10.1089/cpb.2008.0263

O'Keeffe, G., Clarke- Pearson, K. (2012). The impact of social media on children, adolescents, and families. Social Journal, 11(3), 142- 150.

Pooran, N. (2012). 100 crimes on Facebook in only one police area. The property of Solo Syndication Ltd.

Pooran, N. (2013). 100 crimes on Facebook in only one police area. Database: Regional Business News,Daily Mail, 7/27/2013, p29.

Scherer, M. B. (2012). Nonprofit Organizations and Facebook Use (a master thesis of Liberal Studies, University of Toledo). Retrieved from http://etd.ohiolink.edu/sendpdf.

Virden, A., Trujillo, A., \& Predeger, E. (2014). Young Adult Females' Perceptions of High-Risk Social Media Behaviors: A Focus-Group Approach. the Journal of Community Health Nursing, 31(3), 133-144. https://doi.org/10.1080/07370016.2014.926677

Young, D.; Szekeres, G., \& Coates, T. (2013). The Relationship Between Online Social Networking And Sexual Risk Behaviors Among Men Who Have Sex With Men (MSM). Search Complete, Summer Educators' Conference Proceedings, 8(5), 412-423. https://doi.org/10.1371/journal.pone.0062271

Zephora Inc. (2015). The Top 20 Valuable Facebook Statistics - Updated May 2015. Retrieved from Https://Zephoria.Com

\section{Copyright Disclaimer}

Copyright for this article is retained by the author(s), with first publication rights granted to the journal.

This is an open-access article distributed under the terms and conditions of the Creative Commons Attribution license (http://creativecommons.org/licenses/by/4.0/). 